\title{
Free amino nitrogen in sweet wort made from barley varieties tested in the Czech Republic
}

\author{
Vratislav Psota* \\ Research Institute of Brewing and Malting, Mostecká 971/7, \\ 61400 Brno, Czech Republic
}

*Corresponding author: psota@beerresearch.cz

\begin{abstract}
The effect of the variety on the free amino nitrogen (FAN) content in wort was studied in the set of 24 varieties grown for a three-year period at four different testing sites. FAN was determined by the EBC 4.10 method. The highest average FAN was exhibited by the variety KWS Amadora $(193 \mathrm{mg} / \mathrm{l})$. The content of FAN was mostly affected by the year (24\%), followed by the site (15\%); the effect of the variety was the lowest (13\%). Nearly $50 \%$ of the samples exhibited low FAN, slightly over $40 \%$ of the samples had medium FAN and $12 \%$ of the samples exhibited high FAN.
\end{abstract}

Key words: barley, sweet wort, free amino nitrogen, malting quality

\section{Introduction}

Quality of malt has a significant effect on the brewing process and the final product quality. Most of the characters assessed in malt, and namely sweet wort, can be split into three groups. These characters describe the result of the activity of cytolytic, proteolytic and amylolytic enzymes.

Proteolytic modification describes degradation of nitrogenous substances and their conversion to low-, medium- and high-molecular soluble forms. Too low degradation of nitrogenous substances causes insufficient supply of yeast with nitrogen compounds, which results in insufficient yeast proliferation and formation of undesirable fermentation by-products (eg diacetyl). Too high protein degradation leads to strong degradation of high molecular weight proteins. The lack of high molecular weight proteins as well as the excess of medium-molecular compounds and amino acids lysine, arginine and histidine has a negative effect on foam stability. Furthermore, sweet worts and beers made from over-modified malts are more intense in colour (Back, 2005).

The content of soluble nitrogen, Kolbach index, and free amino nitrogen (FAN) are the principal parameters characterizing proteolytic modification.
The importance of nitrogenous substances for malt and beer production and their quality is significant (Pierce, 1987). The total content of nitrogenous substances in barley grain is mainly affected by growing conditions at the given locality in a particular year. The quantity of nitrogenous substances in malt and content of the total soluble nitrogen in sweet wort is affected by the content of nitrogenous substances in non-malted grain, variety and malting technology. Only part of nitrogen passes from the malt to the sweet wort. Total soluble nitrogen affects the technological process of beer production and the sensory properties of the final product. The values of the soluble nitrogenous substances usually range from 650 to $950 \mathrm{mg} / \mathrm{l}$.

Kolbach index informs about the ratio of nitrogen that comes from the malt to the laboratory wort. Kolbach index is the most commonly used parameter characterizing proteolytic modification. It expresses the ratio of soluble nitrogen substances determined in wort to the total content of nitrogenous substances in malt. The values of this character usually range from 36 to $44 \%$.

Brewer's yeast receives nitrogen in the form of amino acids, peptides, and ammonium ions produced by proteolysis of barley nitrogenous substances (Clapperton, 1971; 
O'Connor-Cox and Ingledew, 1989). Amino acids, ammonium ions and peptides (di- and tripeptides) required for the synthesis of cell proteins and other yeast cell compounds are referred to as free amino nitrogen (FAN) (Pugh at al., 1997). FAN should form approximately $21-22 \%$ of the total soluble nitrogen, its content in wort most often ranges from 120 to 200 mg/l (Kofroň et al., 2006; Psota et al., 2018).

FAN helps to ensure a sufficient activity of hydrolytic enzymes and a necessary level of fermentation. The levels of FAN in sweet wort inform on the level of malt proteolysis, since amino acids are released mainly during malting. FAN and its composition are considered an important parameter for predicting the fermentation intensity and sensory quality of beer (Inoue and Kashihara, 1995; Baldus et al., 2018).

The amount of the individual amino acids that the FAN contains is also the source of a number of fermentation by-products, including diacetyl and acetolactate, which may affect the resulting taste and sensory stability of beer (Mändl and Wagner, 1978; Pickerell, 1986; Sablayrolles and Ball, 1995; Malfliet et al., 2008; Lei et al., 2012; He et al., 2014; Meier-Dörnberg et al., 2017; Ferreira and Guido, 2018). FAN not consumed during fermentation can serve mainly as a nutrient for the development of undesirable microorganisms in non-pasteurized beer.

\section{Material and methods}

The effect of the variety on the free amino nitrogen content in sweet wort was studied in 2014-2016 in the set of 24 varieties of spring malting barley (Table 1). Every year this set of varieties was obtained from four various testing sites. The testing sites were selected so that the content of nitrogenous substances in the samples of non-malted grain of the studied varieties was around $11 \%$. A total of 288 barley grain samples were assessed.

The summary of the studied parameters is given in Table 2 including the references to the used methods. FAN was determined by the method 4.10 Free amino nitrogen of malt by spectrophotometry (EBC Analysis committee, 2010).

After harvest, malt was produced from the studied varieties. The samples graded on $2.5 \mathrm{~mm}$ sieve were malted. Malting of the samples $(0.5 \mathrm{~kg})$ was conducted in the micromalting plant of the KVM company (CR). Laboratory malting was carried out by the method traditionally used in RIBM, which is almost identical with the MEBAK method (2011). Steeping was conducted in the steeping box. The temperature of water and temperature of air were kept at $14.0^{\circ} \mathrm{C}$.
Table 1 Spring barley varieties

\begin{tabular}{|c|c|c|}
\hline Variety & Year of registration & Country of origin \\
\hline Bojos & 2005 & CZE \\
\hline Francin & 2014 & CZE \\
\hline Kampa & 2015 & FRA \\
\hline Kangoo & 2008 & NLD \\
\hline KWS Amadora & 2015 & DEU \\
\hline KWS Irina & 2014 & DEU \\
\hline Laudis 550 & 2013 & CZE \\
\hline Leenke & 2017 & DEU \\
\hline LG Monus & 2017 & CZE \\
\hline Libuše & 2016 & DEU \\
\hline Malz & 2002 & CZE \\
\hline Manta & 2016 & DEU \\
\hline Octavia & 2017 & GBR \\
\hline Odyssey & 2014 & GBR \\
\hline Overture & 2014 & GBR \\
\hline Petrus & 2013 & CZE \\
\hline Pop & 2017 & FRA \\
\hline Remark & 2017 & DEU \\
\hline Sebastian & 2005 & DNK \\
\hline Soulmate & 2017 & DNK \\
\hline Sunshine & 2012 & DEU \\
\hline Tango & 2016 & FRA \\
\hline Vendela & 2013 & DEU \\
\hline Xanadu & 2006 & DEU \\
\hline
\end{tabular}

\section{Note}

CZE - Czech Republic

DNK - Denmark

GBR - United Kingdom of Great Britain

FRA - France

NLD - Netherlands

DEU - German
Length of steeping: 1 st day - 5 hours; 2nd day - 4 hours. On the third day the water content in germinating grains was adjusted to the value of $45 \%$ by steeping or spraying.

Germination was conducted in the germination box. The temperature during germination was $14.0{ }^{\circ} \mathrm{C}$. The total time of steeping and germination was $144 \mathrm{~h}$. Kilning was performed on a one-floored electrically heated kiln. The total kilning time was $22 \mathrm{~h}$, prekilning at $55^{\circ} \mathrm{C}$, kilning temperature was $80^{\circ} \mathrm{C}$ for 4 hours.

Many quality parameters were assessed in the produced malt and sweet wort (EBC Analysis committee, 2010; MEBAK, 2011; Baxter and O' Farrell, 1983) (Table 2). Notes to some parameters given in the table: Wort clarity is assessed as follows: 1 = clear, 2 = weakly opalizing, 3 = opalizing, 4 = cloudy. Malt yield in dry matter (\%) = weight of deculmed malt in dry matter $/$ (weight of barley in dry matter/100). Respiration losses (\%) = $100-$ (malt yield in dry matter + rootlet losses). Rootlet losses $(\%)=100$ - weight of deculmed malt / (weight of non-deculmed malt/100) (Briggs, 1998). 
Table 2 Correlation and regression coefficient of FAN

\begin{tabular}{|c|c|c|c|c|c|}
\hline Method & Unit & Reference & r & reg & Sign. \\
\hline Bulk density of barley $\mathrm{d} . \mathrm{m}$. & $\mathrm{kg}$ & & 0.04 & 0.01 & NS \\
\hline Protein content of barley (factor 6.25) & $\%$ & EBC, 2010 & 0.08 & 0.00 & NS \\
\hline Starch content of barley & $\%$ & NIR & 0.17 & 0.01 & $* *$ \\
\hline Degree of steeping 1 & $\%$ & & 0.01 & 0.00 & NS \\
\hline Degree of steeping 2 & $\%$ & & 0.01 & 0.00 & NS \\
\hline Extract of malt, congress mash & $\%$ & EBC, 2010 & 0.32 & 0.02 & $* * *$ \\
\hline Mash method according to Hartong and Kretschmer VZ $45^{\circ} \mathrm{C}$ & $\%$ & MEBAK, 2011 & 0.41 & 0.08 & $* * *$ \\
\hline Kolbach index & $\%$ & EBC, 2010 & 0.41 & 0.07 & $* * *$ \\
\hline Diastatic power & WK & EBC, 2010 & 0.13 & 0.39 & * \\
\hline Final attenuation of laboratory wort from malt & $\%$ & EBC, 2010 & 0.14 & 0.01 & * \\
\hline Friability & $\%$ & EBC, 2010 & 0.13 & 0.04 & * \\
\hline High molecular weight $\beta$-glucan content of malt, FIA & $\mathrm{mg} / \mathrm{l}$ & EBC, 2010 & -0.21 & -1.01 & *** \\
\hline Protein content of malt (factor 6.25 ) & $\%$ & EBC, 2010 & 0.13 & 0.00 & * \\
\hline Total nitrogen of malt, Kjeldahl method & $\%$ & EBC, 2010 & 0.13 & 0.00 & $*$ \\
\hline Soluble nitrogen of wort, Kjeldahl method & $\mathrm{mg} / \mathrm{l}$ & EBC, 2010 & 0.58 & 1.65 & $* * *$ \\
\hline Soluble nitrogen of malt, Kjeldahl method & $\%$ & EBC, 2010 & 0.58 & 0.00 & $* * *$ \\
\hline Viscosity of laboratory wort from malt & $\mathrm{mPa} . \mathrm{s}$ & EBC, 2010 & -0.30 & 0.00 & $* * *$ \\
\hline Total polyphenols in wort & $\mathrm{mg} / \mathrm{l}$ & EBC, 2010 & 0.12 & & * \\
\hline Colour of malt, visual method & $\mathrm{EBC}$ & EBC, 2010 & 0.16 & 0.00 & $* *$ \\
\hline Glassy corns & $\%$ & EBC, 2010 & -0.04 & 0.00 & NS \\
\hline Partly unmodified grains & $\%$ & EBC, 2010 & -0.08 & -0.01 & NS \\
\hline Homogeneity (by friabilimeter) & $\%$ & Baxter a O'Farrell, 1983 & 0.08 & 0.01 & NS \\
\hline Appearance (clarity) of wort & & MEBAK 2011 & -0.06 & 0.00 & NS \\
\hline Haze of wort $\left(90^{\circ}\right)$ & $\mathrm{EBC}$ & EBC, 2010 & -0.15 & -0.01 & $*$ \\
\hline Haze of wort $\left(12^{\circ}\right)$ & $\mathrm{EBC}$ & EBC, 2010 & -0.10 & 0.00 & NS \\
\hline Respiration losses d. m. & $\%$ & Briggs, 1998 & 0.21 & 0.00 & $* * *$ \\
\hline Rootlet losses d. m. & $\%$ & Briggs, 1998 & 0.23 & 0.00 & $* * *$ \\
\hline Malt yield d. m. & $\%$ & Briggs, 1998 & -0.28 & -0.01 & $* * *$ \\
\hline
\end{tabular}

Note

Sign. - significant level

$r$-correlation coefficient

reg - regression coefficient

NS non significant

The set was evaluated by a three-way analysis variance and the set structure was described by a frequency distribution table and a histogram. A Bonferroni test was used to create homogeneous groups. Furthermore, correlation and regression coefficients between FAN and other studied traits were determined.

\section{Results and discussion}

FAN content in sweet wort is mainly affected by the malting technology used, content of nitrogenous substances in non-malted barley grain and variety. Leach et al. (2002) found that, using different malting conditions, malts with a significant difference in the contents of FAN, soluble ni- trogen, and different activity of hydrolytic enzymes could be produced from the same barley sample. The Canadian two-row barley varieties processed in the pilot malt house were found to have a FAN content of 185-223 mg/l. However, the same varieties processed in industrial malting facilities showed a FAN content of 160-197 mg/l. The difference was definitely caused by different malting conditions and different content of nitrogenous substances in the non-malted barley grain (Li and Egi, 2004). In addition, Back and Narziß (1997) demonstrated that the length and temperature of germination and degree of steeping markedly affected the FAN content.

Within this experiment we tried, through the selection of testing sites in which the grain of the studied varieties showed optimal values of nitrogenous substances 
Table 3 Analysis of variance and estimated components of variance of a) free amino nitrogen, b) soluble nitrogen of wort, c) ratio FAN in soluble nitrogen

a) free amino nitrogen

\begin{tabular}{|l|c|c|c|c|c|c|c|}
\hline \multirow{2}{*}{ Source of variation } & d.f. & \multirow{2}{*}{ Mean square } & $\begin{array}{c}\text { Significant } \\
\text { level }\end{array}$ & \multirow{2}{*}{ F ratio } & \multicolumn{3}{c|}{ Estimated components variance } \\
\cline { 6 - 9 } & & & & & abs. & rel. (\%) & s.e. \\
\hline Year & 2 & 8257 & $* * *$ & 24.66 & 132 & 20 & 140 \\
\hline Site & 7 & 3517 & $* * *$ & 10.51 & 98 & 15 & 61 \\
\hline Variety & 23 & 1305 & $* * *$ & 3.90 & 81 & 13 & 52 \\
\hline Residual & 255 & 335 & & & 336 & 52 & 30 \\
\hline
\end{tabular}

b) soluble nitrogen of wort

\begin{tabular}{|l|c|c|c|c|c|c|c|}
\hline \multirow{2}{*}{ Source of variation } & \multirow{2}{*}{ d.f. } & \multirow{2}{*}{ Mean square } & \multirow{2}{*}{$\begin{array}{c}\text { Significant } \\
\text { level }\end{array}$} & \multirow{2}{*}{ F ratio } & \multicolumn{3}{c|}{ Estimated components of variance } \\
\cline { 6 - 9 } & & & & & abs. & rel. (\%) & s.e. \\
\hline Year & 2 & 42010 & $* * *$ & 27.41 & 637 & 12 & 670 \\
\hline Site & 7 & 43714 & $* * *$ & 28.52 & 1780 & 33 & 987 \\
\hline Variety & 23 & 18259 & $* * *$ & 11.91 & 1394 & 26 & 449 \\
\hline Residual & 255 & 1533 & & & 1534 & 29 & 136 \\
\hline
\end{tabular}

c) ratio FAN in soluble nitrogen

\begin{tabular}{|c|c|c|c|c|c|c|c|}
\hline \multirow{2}{*}{ Source of variation } & \multirow{2}{*}{ d.f. } & \multirow{2}{*}{ Mean square } & \multirow{2}{*}{$\begin{array}{l}\text { Significant } \\
\text { level }\end{array}$} & \multirow{2}{*}{ F ratio } & \multicolumn{3}{|c|}{ Estimated components of variance } \\
\hline & & & & & abs. & rel. (\%) & s.e. \\
\hline Year & 2 & 50 & $* * *$ & 11.03 & 1.0 & 16.4 & 1.0 \\
\hline Site & 7 & 16 & $* *$ & 3.45 & 0.3 & 5.8 & 0.3 \\
\hline Variety & 23 & 5 & NS & 1.12 & 0.0 & 0.8 & 0.1 \\
\hline Residual & 255 & 5 & & & 4.5 & 77.1 & 0.4 \\
\hline
\end{tabular}

Note $\begin{array}{ll}\text { d.f degrees of freedom } & \text { abs. original value NS non significant } \\ \text { rel. relative value } & \text { s.e. standard error }\end{array}$ ${ }^{* * *} P=0.001 \quad{ }^{* *} P=0.01$

(11.0\% or similar values) and using a uniform malting technology, to suppress in statistical evaluation the effect of nitrogenous substances and malting technology and highlight the effect of varieties on the FAN content in sweet wort. Despite this effort, the FAN content of the sweet wort in the studied set of varieties was influenced from $20 \%$ by the year, $15 \%$ by the site and only from $13 \%$ by the variety. Non-monitored sources of variability formed more than $50 \%$ (Table 3). The low influence of the variety on the FAN content was probably due to the small variability of the set. The studied set contained only good quality spring barley malting varieties. Most samples (63\%) ranged from $151-195 \mathrm{mg} / \mathrm{l} .30 \%$ of the samples exhibited the FAN content in the range from $90-150 \mathrm{mg} / \mathrm{l}$. Only $7 \%$ of the samples had higher FAN content (196-240 $\mathrm{mg} / \mathrm{l}$ ) (Figure 1). According to the average FAN content, the set of the studied spring barley varieties was divided into four homogeneous groups that overlapped each other (Table 4). Only the varieties Kampa and Petrus exhibited the average FAN content up to $150 \mathrm{mg} / \mathrm{l}$. All other varieties had an average FAN content in the range from
151-193 mg/l. None of the studied varieties showed an average value higher than $195 \mathrm{mg} / \mathrm{l}$ (Table 4).

Requirements of breweries for the FAN content may vary significantly.Varieties suitable for breweries that add non-malted grain of barley or other cereals to malt, are bred in the USA. For this reason, they require barley varieties that provide malt with a higher FAN content, a high level of diastatic power and Kolbach index (Hertrich, 2013). Pitz (1990) reported the FAN content in North American two-row varieties in the range from 180 to $220 \mathrm{mg} / \mathrm{l}$ and in six-row varieties from 160 to $210 \mathrm{mg} / \mathrm{l}$. Hertrich (2013) reported FAN values of up to $235 \mathrm{mg} / \mathrm{l}$ in North American barley varieties. European varieties have lower FAN levels. The American Brewers Association (2014) associating craft breweries reports that the FAN content should be at least $150 \mathrm{mg} / \mathrm{l}$. The requirements of the craft breweries for FAN content ranged from 120 to $200 \mathrm{mg} / \mathrm{l}$.

The absolute value of the FAN content has been shown to be less important than the FAN to soluble nitrogen ratio (Back and Narziß, 1997). The ratio of FAN in soluble nitrogen varied between $12.31 \%$ and $26.01 \%$ in the 
Table 4 Multiple range analysis for free amino nitrogen in sweet wort $(\mathrm{mg} / \mathrm{l})$

\begin{tabular}{|l|l|l|l|l|l|}
\hline \multicolumn{1}{|c|}{ Variety } & Mean & \multicolumn{4}{c|}{$\begin{array}{l}\text { Homogeneous } \\
\text { groups }\end{array}$} \\
\hline Kampa & 144 & a & & & \\
\hline Petrus & 147 & a & b & & \\
\hline Octavia & 151 & a & b & c & \\
\hline KWS Irina & 155 & a & b & c & \\
\hline Vendela & 156 & a & b & c & \\
\hline Manta & 156 & a & b & c & \\
\hline Kangoo & 156 & a & b & c & \\
\hline LG Monus & 157 & a & b & c & \\
\hline Francin & 157 & a & b & c & \\
\hline Laudis 550 & 157 & a & b & c & \\
\hline Sebastian & 158 & a & b & c & \\
\hline Bojos & 158 & a & b & c & \\
\hline Leenke & 159 & a & b & c & \\
\hline Odyssey & 159 & a & b & c & \\
\hline Pop & 164 & a & b & c & \\
\hline Tango & 164 & a & b & c & \\
\hline Overture & 175 & & b & c & d \\
\hline Soulmate & 165 & a & b & c & \\
\hline Malz & 169 & & & c & d \\
\hline Remark & 163 & & & & d \\
\hline Libuše & 169 & a & b & c & d \\
\hline Sunshine & 169 & b & c & d \\
\hline Xanadu & 176 & b & c & d \\
\hline KWS Amadora & 169 & d \\
\hline
\end{tabular}

Table 5 Multiple range analysis for FAN ratio in soluble nitrogen (\%)

\begin{tabular}{|c|c|c|}
\hline Variety & Mean & $\begin{array}{l}\text { Homogeneous } \\
\text { groups }\end{array}$ \\
\hline Leenke & 19.4 & a \\
\hline Kangoo & 19.6 & a \\
\hline Bojos & 19.6 & a \\
\hline Laudis 550 & 19.6 & a \\
\hline Petrus & 19.7 & a \\
\hline Octavia & 19.8 & a \\
\hline Sunshine & 19.9 & a \\
\hline Pop & 20.0 & a \\
\hline KWS Irina & 20.0 & a \\
\hline Francin & 20.1 & a \\
\hline Kampa & 20.1 & a \\
\hline Malz & 20.2 & a \\
\hline Libuše & 20.4 & a \\
\hline Overture & 20.4 & a \\
\hline Vendela & 20.4 & a \\
\hline Sebastian & 20.4 & a \\
\hline Manta & 20.5 & a \\
\hline Remark & 20.6 & a \\
\hline Odyssey & 20.7 & a \\
\hline Soulmate & 20.9 & a \\
\hline Tango & 20.9 & a \\
\hline LG Monus & 21.0 & a \\
\hline Xanadu & 21.2 & a \\
\hline KWS Amadora & 22.3 & $a$ \\
\hline
\end{tabular}

Figure 1 FAN distribution in a set of samples of monitored spring barley varieties

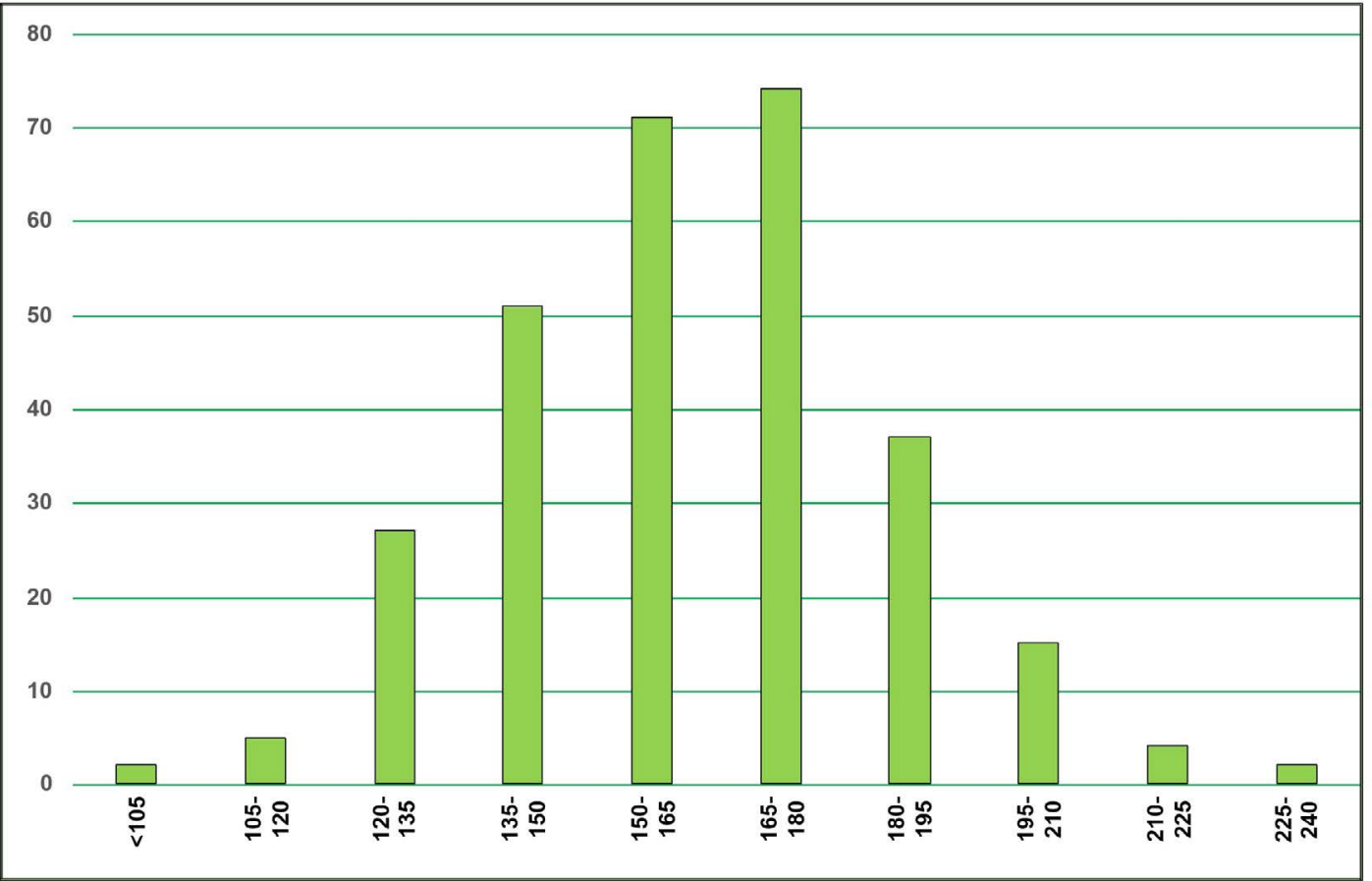


studied set of varieties. The lowest average ratio of FAN in soluble nitrogen was reported by Leenke (19.37\%). The highest ratio of FAN in the soluble nitrogen content was recorded in KWS Amadora (22.34\%). However, there was no statistically significant difference between the varieties (Table 5). It was found that for good fermentation and yeast multiplication and standard level of fermentation by-products (Gibson et al., 1985).

FAN in sweet wort should form $20-22 \%$ of the soluble nitrogen (Mändl and Wagner, 1978; Back and Narziß, 1997); this was fulfilled by the studied varieties.

The FAN content was in weak to moderate relationship with the parameters characterizing, in a certain way, mainly the proteolytic and cytolytic modification of the caryopsis endosperm. The relationship between the FAN content and content of soluble nitrogen $(r=0.58)$ and also Kolbach index and relative extract at $45^{\circ} \mathrm{C}(\mathrm{r}=0.41)$ was moderately strong (Table 2). The correlation between FAN and relative extract was also reported by Back and Narziß (1997).

The relationship between the FAN content and extract content $(r=0.32)$ was weak. A negative weak relationship was recorded between the contents of FAN and beta-glucans in sweet wort $(r=-0.21)$ and viscosity $(\mathrm{r}=-0.30)$. With decreasing cytolytic modification, FAN content decreased. A similar situation occurred in losses by malting. Increasing respiration losses $(r=0.21)$ and deculming losses ( $r=0.23$ ) are mostly an indicator of a higher level of modification; FAN content increases with a higher level of modification. The opposite situation obtains in the case of malt yield $(r=-0.28)$. FAN content decreases as yield increases. Other traits were very weakly related to the FAN content. Although FAN affects yeast activity, no significant relationship between FAN content and achievable degree of fermentation was observed (Table 2). Conversely, with increasing malt yield $(r=-0.28)$ the content of FAN decreases. The relationship of the other studied parameters to the FAN content was weak. Although FAN affects the activity of yeast, no more significant relationship between the FAN content and apparent final attenuation was detected (Table 2).

\section{Conclusion}

The present study was performed on a collection of 24 spring barley malting varieties. The free amino nitrogen content was studied in the sweet wort made from these varieties.

In the studied set, the FAN content in sweet wort was influenced from $20 \%$ by the year, $15 \%$ by the site and only from $13 \%$ by the variety. The average FAN content up to $150 \mathrm{mg} / \mathrm{l}$ was recorded in Kampa and Petrus, the other varieties had an average FAN content in the range of $151-193 \mathrm{mg} / \mathrm{l}$. The ratio of FAN in the soluble nitrogen content in the studied set of varieties moved in the range of $12.31 \%$ to $26.01 \%$. Moderately strong relationship was detected between the contents of FAN and soluble nitrogen $(r=0.58)$ and Kolbach index and relative extract at $45^{\circ} \mathrm{C}(\mathrm{r}=0.41)$, i.e. parameters characterizing proteolytic modification. FAN significantly affects fermentation and its composition affects the resulting taste and sensory stability of the final product.

\section{Acknowledgement}

The results were obtained with the support of the Ministry of Education, Youth and Sports of the Czech Republic - Research Sensory Centre in Prague and Research and Development Centre - Sustainability and Development (L01312).

\section{References}

Back, W., 2005: Ausgewählte Kapitel der Brauereitechnologie. Fachverl, Carl, Nürnberg. ISBN 10: 341800802X

Back, W., Narziß, L., 1997: Malt parameters and beer quality, Brauwelt International 15(1): 29- 35.

Baldus, M., Klie, R., Biermann, M., Kreuschner, P., Hutzler, M., Methner, F. J., 2018: On the behaviour of dimethyl sulfoxide in the brewing process and its role as dimethyl sulfide precursor in beer. Brewing Science 71(1): 1-11. DOI: 10.23763/BrSc18-01baldus

Baxter, E. D., O'Farrell, D. D., 1983: Use of the friabilimeter to assess homogeneity of malt. J. Inst. Brew. 89(3): 210-214. https://doi. org/10.1002/j.2050-0416.1983.tb04169.x

Brewers Association, 2014. Malting barley characteristics for craft brewers. Brewers Association. https://www.brewersassociation.org/ best-practices/malt/malting-barley-characteristics/.

Briggs, D. E., 1998: Malts and malting. Blackie Academic, and Professional, London 1998. ISBN-10: 0412298007

Clapperton, J. F., 1971: Simple peptides of wort and beer. J. Inst. Brew. 77(2):177-180. https://doi.org/10.1002/j.2050-0416.1971.tb03371.x

EBC Analysis committee, 2010: Analytica-EBC. Nüremberg: Fachverlag Hans Carl, 794 p. ISBN 978-3-418-00759-5.

Ferreira, I. M., Guido, L. F., 2018: Impact of wort amino acids on beer flavour: A Review. Fermentation 4, 23. https://doi.org/10.3390/fermentation4020023

Gibson, R. M., Large, P. J., Bamforth, C. W., 1985: The influence of assimilable nitrogen compounds in wort on the ability of yeast to reduce dimethyl sulphoxide, J. Inst. Brew., 91(6): 401-405. https://doi. org/10.1002/j.2050-0416.1985.tb04364.X

He, Y., Dong, J., Yin, H., Zhao, Y., Chen, R., Wan, X., Chen, P., Hou, X., Liu, J., Chen, L., 2014: Wort composition and its impact on the flavour-active higher alcohol and ester formation of beer - A review. J. Inst. Brew. 120(3): 157-163. https://doi.org/10.1002/jib.145

Hertrich, J., 2013: Topics in Brewing: Malting barley. Tech. Q. Master Brew. Assoc. Am. 50(1): 29-41

Inoue, T., Kashihara, T., 1995: The importance of indices related to nitrogen metabolism in fermentation control, Tech. Q. Master Brew. Assoc. Am. 32(2): 109-113. 
Kofroň, P., Skoblík, R., Enge, J., Sekora, M., 2006: Testing of malting barley - Variety Bojos. Kvasny Prum. 52(6): 179-184. https://doi. org/10.18832/kp2006016

Leach, R., Li, Y., Edney, M., Izydorczyk, M., Egi, A., Sawatzky, K., 2002: Effects of barley protein content on barley endosperm texture, processing condition requirements, and malt and beer quality. Tech. Q. Master Brew. Assoc. Am. 39(4): 191-202.

Lei, H., Zhao, H., Yu, Z., Zhao, M., 2012: Effects of wort gravity and nitrogen level on fermentation performance of brewer's yeast and the formation of flavor volatiles, Appl. Biochem. Biotechnol. 166(6), 1562-1574. https://doi.org/10.1007/s12010-012-9560-8

Li, Y., Egi, A., 2004: New Canadian malting barley varieties and their malting and brewing characteristics Tech. Q. Master Brew. Assoc. Am. 41(2): 104-110.

MEBAK, 2011: Raw materials. Collection of brewing analysis methods of the Mitteleuropäische Brautechnische Analysenkommission (MEBAK), Freising-Weihenstephan, Germany. 2011. $341 \mathrm{p}$

Malfliet, S., Van Opstaele, F., De Clippeleer, J., Syryn, E., Goiris, K., De Cooman, L., Aerts, G., 2008: Flavour instability of pale lager beers: Determination of analytical markers in relation to sensory ageing. Journal of the Institute of Brewing, 114 (2), 180-192. https://doi. org/10.1002/j.2050-0416.2008.tb00324.x

Mändl, B., Wagner, D., 1978: Zum Einfluß der Maischbedingungen auf die Aminosäurenversorgung der Hefe. Brauwissenschaft, 31(8): 213-221.
Meier-Dörnberg, T., Hutzler, M., Michel, M., Methner, F. J., Jacob, F., 2017: The Importance of a Comparative Characterization of Saccharomyces Cerevisiae and Saccharomyces Pastorianus Strains for Brewing. Fermentation 3, 41. https://doi.org/10.3390/fermentation3030041

O'Connor-Cox, E. S. C., Ingledew, W. M., 1989: Wort nitrogenous sources Their use by brewing yeasts: A review. J. Am. Soc. Brew. Chem. 47(4): 102-108. https://doi.org/10.1094/ASBCJ-47-0102

Pickerell, A. T. W., 1986: The influence of free alpha-amino nitrogen in sorghum beer fermentations, J. Inst. Brew. 92(6): 568-571. https://doi. org/10.1002/j.2050-0416.1986.tb04455.x

Pierce, J. S., 1987: The role of nitrogen in brewing. J. Inst. Brew. 93(5): 378-381. https://doi.org/10.1002/j.2050-0416.1987.tb04520.x

Pitz, W. J., 1990: An Analysis of Malting Research. J. Am. Soc. Brew. Chem. 48(1): 33-43. https://doi.org/10.1094/ASBCJ-48-0033

Psota, V., Dvořáčková, O., Nečas, M., Musilová, M., 2018: Barley varieties registered in the Czech Republic after harvest 2017. Kvasny Prum. 64(3): 102-110. https://doi.org/10.18832/kp201817

Pugh, T. A., Maurer, J. M., and Pringle, A. T., 1997: The impact of wort nitrogen limitation on yeast fermentation performance and diacetyl, Tech. Q. Master Brew. Assoc. Am. 34(3): 185- 189.

Sablayrolles, J. M., Ball, C. B., 1995: Fermentation kinetics and the production of volatiles during alcoholic fermentation, J. Am. Soc. Brew. Chem. 53(2): 71-78. https://doi.org/10.1094/ASBCJ-53-0072 